\title{
Probing transfer of an IncP replicon to natural marine bacteria*
}

\author{
Ensayo de transferencia de un replicón IncP a bacterias marinas naturales \\ James Robeson and Ana María Skarmeta \\ * This paper is dedicated to the memory of Dr. Manuel Rodríguez Leiva \\ Instituto de Biología, Universidad Católica de Valparaíso. Avenida Brasil 2950, Valparaíso, Chile. \\ jrobeson@ucv.cl
}

\begin{abstract}
An IncP plasmid probe (pUCV2), coding for $\mathrm{Cm}-\mathrm{r}, \mathrm{Km}-\mathrm{r}$ and bearing Ap (am) and Tc (am) resistance determinants was constructed by transposition of $\operatorname{Tn} 9(\mathrm{Cm}-\mathrm{r})$ onto plasmid pLM2 for an efficient selection of potential recipients among natural marine bacteria. Using a Dap $E$. coli donor, transmission of pUCV2 to marine bacteria was tested. pUCV2 is transferred to about $4-8 \%$ of natural, marine bacterial cells capable of forming colonies on a low nutrient, marine agar medium. The following bacterial genera, commonly found in the marine environment, could be detected when twenty of the transconjugant colonies obtained were identified: Vibrio, Pseudomonas and Aeromonas.
\end{abstract}

Keywords: Horizontal transfer, IncP probe, marine bacteria.
Resumen.- Una sonda plasmidial IncP (pUCV2), que codifica para $\mathrm{Cm}-\mathrm{r}, \mathrm{Km}-\mathrm{r}$ y que tiene determinantes de resistencia Ap (am) y Tc (am) fue construida por transposición de $\operatorname{Tn} 9(\mathrm{Cm}-\mathrm{r})$ al plásmido $\mathrm{pLM} 2$, para una eficiente selección de potenciales receptores entre bacterias marinas naturales. Usando un donador E. coli Dap', se ensayó la transmisión de pUCV2 a bacterias marinas. pUCV2 es transferido a cerca del $4-8 \%$ de las células bacterianas marinas naturales, capaces de formar colonias en un medio de agar marino con bajos niveles de nutrientes. Los siguientes géneros bacterianos, comúnmente encontrados en el ambiente marino, pudieron ser detectados cuando veinte de las colonias transconjugantes obtenidas fueron identificadas: Vibrio, Pseudomonas y Aeromonas.

Palabras clave: Transferencia horizontal, sonda IncP, bacterias marinas.

\section{Introduction}

The carriage of plasmids by antibiotic-resistant marine bacteria was described in a pioneering study by Sizemore \& Colwell (1977). However, only recently more attention has been devoted to the nature of such plasmids and their potential for horizontal transfer. In this vein, resistance plasmids have been described for bacteria in the marine air-water interface (Hermansson et al. 1987), in marine sediments (Sobecky et al. 1997, 1998) and other marine habitats (Dahlberg et al. 1997). This seems relevant to the emergence of antibioticresistant marine bacteria in aquafarming as its has been revealed by studies of Sandaa et al. (1992), who found transferable drug resistance among bacteria from fishfarm sediments and showed dispersal of a promiscuous plasmid from Aeromonas salmonicida to bacteria in marine sediments (Sandaa \& Enger 1994).

Besides plasmids in indigenous marine bacteria, those carried by allochthonous bacteria that enter the marine environment are also considered a potential source of genetic variation for marine bacteria, in the event that heterologous transmission takes place and the allochthonous plasmids are stabilized in the marine bacterial recipients. This situation was perceived in an early study by Patt et al. (1972), who showed transfer of Escherichia coli plasmids to marine bacteria. In this regard, promiscuous plasmids in Gram negative bacteria, such as the IncP replicon RP4 (Smith \& Thomas 1989) are prime candidates for such a role because they are capable of transfer to different genera of Proteobacteria (Hodgson 1989), a dominant group among marine bacteria (González \& Moran 1997).

Studies pertaining transfer of IncP plasmids to marine bacteria are overall very scarce. Goodman et al. (1993) have shown transfer of RP1 between E. coli and strains of the marine Vibrio S14 under starvation conditions in artificial seawater. Furthermore, Sorensen (1993) demonstrated transfer of RP4 from E. coli to different marine bacterial isolates in filter crosses and in sterile seawater and to indigenous marine bacteria using an auxotrophic donor strain to select transconjugants on selective minimal media. In addition, Sandaa (1993) used Vibrio sp. S141, containing RP4, as a genetic donor in experiments to detect plasmid transfer and maintenance in marine sediments with marine bacterial isolates acting as genetic recipients. In this 
investigation, no transfer was detected to the marine recipients, in spite of the fact that the plasmid was maintained for more than 67 days in the released host.

Within the latter context, in the study we hereby report we aimed at developing a selection based strategy for the facile investigation of the dispersal of IncP replicons from an $E$. coli donor to a wide range of natural marine bacteria, using a genetically tagged plasmid probe.

\section{Materials and methods}

\section{Bacteriological techniques}

The main bacterial strains and plasmids used in this work are listed in Table 1. Additional bacterial strains are described in Tables 2 and 3. E. coli strains were routinely grown at $37^{\circ} \mathrm{C}$, unless otherwise indicated, in L medium (Robeson \& Skarmeta, 1998). Marine bacteria were grown at $25^{\circ} \mathrm{C}$ in a marine medium prepared in $75 \%$ seawater that contained in $\mathrm{g} / \mathrm{l}$ : Bactopeptone, 5 and Yeast extract, 1. For plates, agar was added at $1.5 \%$ (MA). Low Nutrient (LN) medium was as MA, but with Bactopeptone and Yeast Extract 100 fold less concentrated. Mc Conkey agar base supplemented with $1 \%$ sugar was used as indicator medium.
Antibiotics were used in the following concentrations in $\mu \mathrm{g} / \mathrm{ml}$ : Ampicillin (Ap), 50; Chloramphenicol (Cm), 20; Kanamycin (Km), 50; Nalidixic acid (Nal), 100; Tetracycline (Tc), 25 and Streptomycin (Sm), 200. Diaminopimelic acid (Dap) was used at $50 \mu \mathrm{g} / \mathrm{ml}$. All media were from Difco (Detroit, Mi.) and supplements from Sigma (St. Louis, Mo.).

Characterization of marine bacterial isolates by biochemical tests and physiological features was according to Smibert \& Krieg (1981) and by the API 20B identification system (Bio Mérieux, Montalieu, France).

\section{Genetical techniques}

Conjugative spin matings between donor and recipient strains in Eppendorf centrifuge tubes were as described (Robeson \& Skarmeta, 1998). Surface matings between E. coli strains were performed spreading $2 \times 10^{9}$ cells of each donor and recipient on the surface of $\mathrm{L}$ agar plates, which were incubated for $6 \mathrm{~h}$ at $37^{\circ} \mathrm{C}$ prior to selection of recombinants.

Transfer of the plasmid probe pUCV2 (see below) from $E$. coli VAL1 (Table 1) to natural marine bacteria was detected by a plate transfer assay (Robeson et al., 1990) that consisted in spreading about $1 \times 10^{7}$ washed $E$. coli donor cells on the surface of an LN plate, which was then seeded with $50 \mu \mathrm{l}$ of seawater to allow development of marine bacterial colonies. All potential recipient colonies could then be tested for acquisition of plasmid markers in MA supplemented with $\mathrm{Cm}$ and $\mathrm{Km}$.

For the construction of pUCV2, E. coli VAL2, containing the plasmid pLM2 was spin-mated with $E$. coli VAL53 that contains Tn9 in its chromosome. One of the VAL53 (pLM2) transconjugants obtained was then surface-mated with $E$. coli $\chi 2605$. The bacterial cell mixture was then replica-plated onto McConkey-galactose agar containing $\mathrm{Sm}, \mathrm{Cm}$ and $\mathrm{Km}$ to select E. coli $\chi 2605$ (pLM2::Tn9 $=\mathrm{pUCV} 2$ ) exconjugants.

$\begin{array}{ccc}\mathrm{F}^{-} \text {prototroph } & \text { None } & \text { R. Curtiss III } \\ \mathrm{Gal}^{-}, \mathrm{Sm}-\mathrm{r}, \mathrm{Su}^{0} & & \end{array}$




\section{Results}

To study transfer of IncP replicons to natural marine bacteria our first aim was to construct a suitable IncP plasmid probe that could be genetically recognizable and would allow easy selection of transconjugants. In plating non-polluted seawater samples in the presence of various antibiotics we found that the $\mathrm{Cm}-\mathrm{Km}$ combination was particularly effective in eliminating all background growth of marine bacteria in MA medium. Therefore, we decided to derive an IncP probe containing $\mathrm{Cm}$ and $\mathrm{Km}$ resistance determinants. As a starting base we used plasmid pLM2, an IncP derivative that has amber mutated Ap and Tc resistance genes, which are only expressed in amber supressor (sup E) bacterial strains (Mindich et al., 1976).

We transposed Tn9 onto pLM2 and selected exconjugants of E. coli $\chi 2605$ as Gal- Sm-r colonies that became simultaneously resistant to $\mathrm{Cm}$ and $\mathrm{Km}$. These exconjugants were Ap and Tc sensitive due the fact that $E$. coli $\chi 2605$ is not an amber supressor strain $\left(\mathrm{Su}^{0}\right)$. We finally worked with a plasmid probe designated pUCV2, which conferred the expected phenotypes to sup $E$ and $\mathrm{Su}^{0} E$. coli strains ; it rendered both $E$. coli strains $\chi 2605$ and $\chi 1849$ resistant to $\mathrm{Cm}$ and $\mathrm{Km}$ but only $\chi 1849$ expressed, in addition, Ap and Tc resistance. Furthermore, pUCV2 DNA could be detected as a single plasmid band with increased molecular mass in relation to pLM2 DNA, upon comparison of both molecules in a $0.5 \%$ agarose gel (data not shown). This difference in mass is expected due to insertion of Tn9 into pLM2.

We then tested transfer of pUCV2 from the $E$. coli VAL1 donor to known, typical marine bacteria. We chose this strain because of its inability to synthetize Dap, an essential cell wall component; consequently this donor can be selected against, even in a rich medium by ommiting Dap. Results of these experiments are in Table 2.

In studying transfer of pUCV2 to natural marine bacteria in plate transfer assays we observed that E. coli VAL1, as expected, was unable to form colonies on LN agar plates. However, natural marine bacteria do form small colonies that could be picked and tested for acquisition of the $\mathrm{Cm}$ and $\mathrm{Km}$ resistance markers of pUCV2. When E. coli VAL1 was present in the LN plates, marine bacterial transconjugants could be recovered (Table 3). These bacteria were all Gram negative and most required $\mathrm{NaCl}$ for growth, both predominant features of marine prokaryotes. No $\mathrm{Cm}$ and $\mathrm{Km}$ resistant colonies were recovered from control LN plates without $E$. coli VAL1 cells.
Table 2

\section{Transmission of pUCV2 to culture collection marine bacteria.}

Transmisión de pUCV2 a bacterias marinas de colección.

\begin{tabular}{lcc}
\hline \multicolumn{1}{c}{ Recipient strains $^{\mathrm{a}}$} & $\begin{array}{c}\text { Transfer } \\
\text { Vibrio harveyi BB7 }\end{array}$ & $\begin{array}{c}\text { Frequency of } \\
\text { transfer }^{\mathrm{b}}\end{array}$ \\
Vibrio fischeri MJ-1 & + & $4 \times 10^{-4}$ \\
Deleya marina ATCC 25374 & + & $4 \times 10^{-6}$ \\
Pseudomonas nautica DSM 50418 & + & $4 \times 10^{-5}$ \\
Alteromonas espejiana BAL 31 & - & N.D.
\end{tabular}

${ }^{\text {a }}$ The donor was E. coli VAL1 and the matings were done at $28^{\circ} \mathrm{C}$. Vibrio strains were obtained from Dr. M. Silverman and A. espejiana from Dr. E. Canelo.

${ }^{\mathrm{b}}$ Approximate values expressed as number of transconjugants divided by number of donor cells per $\mathrm{ml}$.

N.D. $=$ not detected.

Table 3

Transfer of pUCV2 to natural marine bacteria in LN marine agar plates.

Transferencia de pUCV2 hacia bacterias marinas naturales en placas de agar marino LN.

\begin{tabular}{cccccc}
\hline $\begin{array}{c}\text { Experiment } \\
\mathrm{N}^{\circ}\end{array}$ & $\begin{array}{c}\text { Mating } \\
\text { Temperature }\end{array}$ & \multicolumn{4}{c}{$\begin{array}{c}\text { Transconjugants/ colonies tested } \\
\text { in sample } \mathrm{N}^{\circ}\end{array}$} \\
& & $\mathrm{I}$ & $\mathrm{II}$ & $\mathrm{III}$ & IV \\
1 & $28^{\circ} \mathrm{C}$ & $12 / 150$ & $7 / 90$ & $5 / 150$ & $22 / 270$ \\
& & $(8 \%)$ & $(7.8 \%)$ & $(3.3 \%)$ & $(8.1 \%)$ \\
2 & $20^{\circ} \mathrm{C}$ & $3 / 80$ & $3 / 80$ & $4 / 82$ & - \\
& & $(3.8 \%)$ & $(3.8 \%)$ & $(4.9 \%)$ & - \\
3 & $7{ }^{\circ} \mathrm{C}$ & $0 / 29$ & $0 / 50$ & $0 / 63$ & - \\
& & $(0 \%)$ & $(0 \%)$ & $(0 \%)$ & \\
& & & & &
\end{tabular}

Several $\mathrm{Cm}-\mathrm{Km}$ resistant marine bacterial transconjugants, which were recovered in MA plates with $\mathrm{Cm}$ and $\mathrm{Km}$ and no Dap, to preclude growth of $E$. coli VAL1, were further purified and examined for plasmid content. In all of them we found plasmid DNA that migrated as pUCV2. Furthermore, they transferred $\mathrm{Cm}$ and $\mathrm{Km}$ resistance to sup $E$ and $\mathrm{Su}^{0} E$. coli strains and thus we could verify the Ap (am) Tc (am) phenotype conferred by pUCV2.

We should mention that we have also tested adding E. coli VAL1 cells to decomposing marine algal material and in one experiment, after incubation at 
room temperature $\left(20-25^{\circ} \mathrm{C}\right)$ for $24 \mathrm{~h}$, we recovered a pUCV2-containing marine bacterium which has not been further characterized.

Finally, some of the selected transconjugants obtained in plate transfer assays were picked at random and identified at the generic level. These results are shown in Table 4.

\section{Table 4}

\section{Bacterial genera of some transconjugants selected with pUCV2.}

Géneros bacterianos de algunos transconjugantes seleccionados con pUCV2.

\begin{tabular}{lc}
\hline Bacterial genera & $\begin{array}{c}\mathrm{N}^{\circ} \text { isolates identified } \\
(\mathrm{n}=20)\end{array}$ \\
Acinetobacter & 2 \\
Aeromonas & 8 \\
Alcaligenes & 2 \\
Pseudomonas & 4 \\
Vibrio & 4 \\
\hline
\end{tabular}

\section{Discussion}

In this work we sought to derive a transmissible plasmid probe that could serve as a model system to easily follow dispersal of IncP type plasmids to natural marine bacteria, based on the assumption that these plasmids are likely candidates for incrementing the pool of accesory DNA elements in marine prokaryotes. The probe pUCV2 seems suitable, in view of the fact that it confers resistance to both $\mathrm{Cm}$ and $\mathrm{Km}$ allowing a powerful selection of marine bacterial recipients of pUCV2. In addition, its use in a Dap E. coli host greatly facilitates selection against the donor.

Our results, regarding transmission of pUCV2 to both laboratory and indigenous strains of marine bacteria, are compatible with the wide host range of an IncP replicon (Smith \& Thomas, 1989). Furthermore, pUCV2 has proven useful as it is transferred to a significant fraction ( 3 to $8 \%$ ) of marine bacterial colony forming units.

These observations suggest that wide host range plasmids such as those of the IncP group, could eventually be established in the gene pool of coastal marine bacteria that come in contact with allochtonous non-marine bacteria that enter the marine environment through terrestrial influxes and/or sewage discharges. This is possible since prolonged survival in seawater of non-marine bacteria like $E$. coli is feasible (Grimes et al. 1986, Ghoul et al. 1995); moreover, this bacterium displays ability to act as a genetic donor in marine microcosms (Sorensen, 1992, 1993; Goodman et al. 1993). Therefore, wide host range plasmids (R-factors) of "terrestrial" origin could contribute to the emergence of antibiotic resistance among marine bacteria many of which are Proteobacteria (Pinhassi et al. 1997) and thus, potential recipients of plasmids contained in allochthonous Gram negative bacteria. Evidence regarding this last point has been recently furnished by Chandrasekaran et al.(1998) who reported conjugative transfer of a multiresistance plasmid from Pseudomonas fluorescens to marine bacteria. Furthermore, plasmid flux from "terrestrial" to marine bacteria could also materialize via transformation (Williams et al. 1997) and transduction (Jiang \& Paul 1998). The group Proteobacteria also contains many bacterial fish pathogens that are becoming increasingly drug resistant (Aoki, 1988) a fact that is compatible with the observations that were pointed out above. Consequently, it is by no means redundant to caution about the uncontrolled use of antibiotics to curtail bacterial infections in aquafarming.

Regarding the properties of the E. coli (Dap') / pUCV2 probe delivery system, it has some advantages. In the first place, it allows selection of natural bacterial transconjugants in rich medium, a situation that favors the recovery of a wide range of culturable bacteria. This seems important insofar colony-forming bacteria, especially Proteobacteria, are dominant in marine bacterioplankton (Pinhassi et al. 1997). Secondly, the Dap ${ }^{-}$host could also be used to deliver other tagged plasmids to the non-culturable fraction of marine bacteria in a manner analogous to that described by Dahlberg et al. (1998) who studied horizontal transfer of a green fluorescent protein (GFP)-tagged plasmid in marine bacterial communities. Thirdly, pUCV2 also allows genetic detection which is less costly and easier to perform than molecular genetic methodology. This could prove to be an advantage in many laboratories. Finally, some concern springs from the fact that a severely debilitated strain such as $E$. coli VAL1 is still proficient as a genetic donor, even in adverse incubation conditions. This reinforces the idea that that laboratory bacterial strains containing natural plasmids or recombinant DNA material should be carefully handled. In summary, we have developed an IncP plasmid probe, contained in a suitable E. coli strain, that allows an efficient tracing of the fate of IncP replicons among bacteria in nature.

\section{Acknowledgements}

We thank the Universidad Católica de Valparaíso and FONDECYT for financial support and Ricardo Pefaur for critical review of the manuscript. 


\section{Literature Cited}

Aoki T. 1988. Drug-resistant plasmids from fish pathogens. Microbiological Sciences 5: 219-223.

Chandrasekaran S, B Venkatesh \& D Lalithakumari. 1998. Transfer and expression of a multiple antibiotic resistance plasmid in marine bacteria. Current Microbiology 5: 347-351.

Dahlberg C, C Linberg, VL Torsvik \& M Hermansson. 1997. Conjugative plasmids isolated from bacteria in marine environments show various degrees of homology to each other and are not closely related to wellcharacterized plasmids. Applied and Environmental Microbiology 63: 4692-4697.

Dahlberg C, M Bergström \& M Hermansson. 1998. In situ detection of high levels of horizontal plasmid transfer in marine bacterial communities. Applied and Environmental Microbiology 64: 2670-2675.

Ghoul M, J Minet, T Bernard, E Dupray \& M Cormier. 1995. Marine macroalgae as a source for osmoprotection for Escherichia coli. Microbial Ecology 30: 171-181.

González JM \& MA Moran. 1997. Numerical dominance of a group of marine bacteria in the $\alpha$-subclass of the class Proteobacteria in coastal seawater. Applied and Environmental Microbiology 63: 4237-4242.

Goodman AE, E Hild, KC Marshall \& M Hermansson. 1993. Conjugative plasmid transfer between bacteria under simulated marine oligotrophic conditions. Applied and Environmental Microbiology 59: 1035-1040.

Grimes DJ, RW Atwell, PR Brayton, LM Palmer, DM Rollins, DB Roszak, FL Singleton, ML Tamplin \& RR Colwell. 1986. The fate of enteric pathogenic bacteria in estuarine and marine environments. Microbiological Sciences 3: 324-329.

Hermansson M, GW Jones \& S Kjelleberg. 1987. Frequency of antibiotic and heavy metal resistance, pigmentation, and plasmids in bacteria of the marine airwater interface. Applied and Environmental Microbiology 53: 2338-2342.

Hodgson DA. 1989. Bacterial diversity: the range of interesting things that bacteria do. In: Hopwood DA \& KF Chater (eds), Genetics of bacterial diversity, pp. 3-22. Academic Press, New York.

Jiang SC \& JH Paul. 1998. Gene transfer by transduction in the marine environment. Applied and Environmental Microbiology 64:2780-2787.

Mindich L, J Cohen \& M Weisburd. 1976. Isolation of nonsense suppressor mutants in Pseudomonas. Journal of Bacteriology 126: 177-182.

Patt T, K Nealson \& C Eberhard. 1972. Promiscuous transfer of genetic information from nonmarine to marine bacteria. The Biological Bulletin 143: 473.

Pinhassi J, UL Zweifel \& A Hagström. 1997. Dominant marine bacterioplankton species found among colonyforming bacteria. Applied and Environmental Microbiology 63: 3359-3366.
Robeson JP, E Grisolía, SV Godoy \& M Quiroz. 1990. Evaluation of enterobacterial plasmid transfer to marine bacteria. In: Castillo G, V Campos \& L Herrera (eds). Proceedings of the second biennial water quality symposium. Microbial aspects, p. 153-158. Editorial Universitaria, Santiago.

Robeson JP \& AM Skarmeta. 1998. Characterization of Escherichia coli strains selectively isolated from seawater. Revista de Biología Marina y Oceanografía 33: 325-330.

Sandaa R-A, VL Torsvik \& J Goksøyr. 1992. Transferable drug resistance in bacteria from fish-farm sediments. Canadian Journal of Microbiology 38: 1061-1065.

Sandaa R-A. 1993. Transfer and maintenance of the plasmid RP4 in marine sediments. Microbial Releases 2: 115-119.

Sandaa R-A \& O. Enger. 1994. Transfer in marine sediments of the naturally occurring plasmid pRAS1 encoding multiple antibiotic resistance. Applied and Environmental Microbiology 60: 4234-4238.

Sizemore RK \& RR Colwell. 1977. Plasmids carried by antibiotic-resistant marine bacteria. Antimicrobial Agents and Chemotherapy 12: 373-382.

Smibert RM \& NR Krieg. 1981. General characterization. In: Gerhard P, RGE Murray, RN Costillow, EW Nester, WA Wood, NR Krieg \& GB Phillips (eds), Manual of Methods for General Bacteriology p. 409-443. American Society for Microbiology, Washington, D.C.

Smith CA \& CM Thomas. 1989. Relationships and evolution of IncP plasmids. In: Thomas CM (ed), Promiscuous Plasmids of Gram Negative Bacteria p. 57-77. Academic Press, London.

Sobecky PA, TJ Mincer, MC Chang \& DR Helinski. 1997. Plasmids isolated from marine sediment microbial communities contain replication and incompatibility regions unrelated to those of known plasmid groups. Applied and Environmental Microbiology 63: 888-895.

Sobecky PA, TJ Mincer, MC Chang, A Toukdarian \& DR Helinski. 1998. Isolation of broad-host-range replicons from marine sediment bacteria. Applied and Environmental Microbiology 64: 2822-2830.

Sorensen SJ. 1992. Mobilization of non-conjugative pBR322derivative plasmids from laboratory strains of Escherichia coli to bacteria isolated from seawater. Microbial Releases 1: 17-22.

Sorensen SJ. 1993. Transfer of plasmid RP4 from Escherichia coli K-12 to indigenous bacteria of seawater. Microbial Releases 2: 135-141.

Williams HG, J Benstead, ME Frischer \& JH Paul. 1997. Alteration in plasmid DNA following natural transformation to populations of marine bacteria. Molecular Marine Biology and Biotechnology 6: 238-247. 